\title{
The Deliberation Of Pancasila Democracy Perpective In The Indonesian Constitutional System
}

\author{
Megawati Megawati, Lecturer of Legal Studies Program, Faculty of Law, Ahmad Dahlan University \\ Indonesia, megawati@law.uad.ac.id,0000-009-3421-0988 \\ Absori Absori, Departmet of Law Universitas Muhammadiyah Surakarta Indonesia, \\ absorisaroni@gmail.com,0000-008-3421-0987
}

\begin{abstract}
The purpose of the study: This research aimed to figure out the deliberation meaning concept in the Indonesia constitutional system as well as the deliberation concept in the Pancasila-based context. This research used the normative study methods by using philosophical approach as the research methodology. According to the results of this research we might conclude that the development, the democracy in Indonesia, in its constitutional practice was more directed to the modern system or in the other word was more directed to the liberalism (western/ election) rather than the traditional system (discussion). Thus the democracy in Indonesia was not in parallel with the aspiration and the purpose of the country arranged by the founder of Indonesia Nation which were aspired by the Pancasila-based nation and 1945 constitution of the Republic Indonesia.
\end{abstract}

Keywords: Deliberation, Democracy, Pancasila.

Received: 14.12.2020 $\quad$ Accepted: 16.01.2021 $\quad$ Published: 05.02.2021

\section{INTRODUCTION}

Indonesia is one of the country in the world using the principle of democracy to perform the national and state life of the nation, as the manisfestation of the community involvement and participation in the organization of the country life which also poured out in the 1945 constitution of the Republic Indonesia preambule or mukadimah. It then described further in the formulation of articles within 1945 constitution of the Republic Indonesia as the values of mass sovereignty, corresponding to the meaning of the democracy stated by The 16th President of United State of America Abraham Lincoln (Period of 18611865), which stated that the democracy was simply interpreted as "the government from the people, by the people, and for the people". Law is a life pattern in the society, due to the willingness of the normal social process by the society, by the presence of a harmony between the prominence of the group life and the personal prominence of the private life. The goal to reach the harmony between the group and the personal prominences were manisfested in the law purpose to reach the harmony between the discipline and the justice, so that it oftenly stated that law was aimed to reach the rechtvaardigeordening der samenleving.(Soerjono Soekanto, 1989). Pancasila from the perspective of Kuntowijoyo (Kompas Daily Newspaper Tuesday February 20, 2003, Pancasila Radicalization), reported that, Pancasila historically had experienced myth and ideological period. Pancasila underwent the "decaying" of its meaning as it became the ideological narrative since the early period we might learn about the democracy until the main figure of New Order (Orde Baru) stepped down the power and authority. (Absori, dkk, 2015). The opening, preambule or mukadimah of the 1945 constitution of the Republic Indonesia showed the philosophical perspective towards the Republic Indonesia Nation as the democratic modern state law (democratische rechstaat) that was the law- based democratic state (constitusional democracy). (Agussalim Andi Gadjong, 2007). In the fourth paragraph of the 1945 constitution of the Republic Indonesia preambule which stated: "National Independence shall be laid down in a constitutional of the state of Indonesia, which is to be established as the state of the Republic of Indonesia with sovereignty of the people". It emphasized that the democracy shared together with the principal of the constitutional state. (Janedjri M. Gaffar , 2013) Democracy was selected based on the value and the equality of the people. As we know etimologically that the word asy syura was taken from the verb of syawara which mean show something or release honey from the bee hive. While the word of deliberation or musyawarah was taken from the Arabic language, syura which was absorbed in the Indonesian with the meaning of discuss and confer. In the Arabic English Dictionary, syura denoted for discussion or consultation.( JM. Cowan, Arabic English Dictionary, 1976). So that etimologically deliberation meaning were stating idea, confer, consult with other people. While terminologically deliberation were the active deeds which were not only fulfilling the voluntary boundaries in the opine, yet liven up from the voluntary to the efforts in the 
opinion or idea statement properly. (Muhammad Imaroh,1998). The founders of Republic Indonesia Nation had established Indonesia as the Unitary State in the ethnic differences from such a long time ago. Therefore in the formation of a nation was done following the principles of deliberation, agreement, and representation as the cornerstone of the implementation in the national and state life to enforce the sovereignty of the people. The cultural order of deliberation already grew up from such a long time before the birth of the Unitary State of Indonesia Republic. Yet at this moment the influence of the western democracy was inevitably therefore it abled to affect the deliberation system as well as the sovereignty of the people democracy in Indonesia from the past time.

One of the reform agenda in Indonesia was the alteration of the national constitution namely 1945 constitution of the Republic Indonesia. The modification or commonly known as the amendment of the 1945 constitution of the Republic Indonesia was an actualization and the completion of the better constitution. Aside from the improvement of the shortcoming of the 1945 constitution of the Republic Indonesia, the renewal also means to enforce the principles that supposed to be maintained properly. 1945 constitution of the Republic Indonesia is a nation constitution which was the goal/ aspiration of the ideal country desired by the nation. the aims of a nation as the guidelines and guides for all the things related to a country and its administration, gave guidelines or guidance related to the State's organizational structure arrangement or the determination of the state's policies.

The renewal of the 1945 constitution of the Republic Indonesia expected to be The Big Law or The Supreme Law of the Land in the Indonesian law system. The main factor to determine the basic constitution renewal was the society condition. The democracy encouragement, the implementation of welfare state (welfare staat), the modification of economical pattern and system affected by the industrialization, the advance of science and technology might become a forces to push the renewal of the basic constitution (Bagir Manan, 2003).

Accordingly, as meant by the democracy-based Nation, the law state is one characteristic of the modern country which expected by all the countries around the world, by the european countries having continental law tradition, England and USA which had the anglo-saxon tradition, Arabic countries which were the islamic contries, communist countries or even the third world countries which were governed by the totalitarian regime for such a long time. (Tamanaha dalam Yance Arizona, 2011).

Consequently, a democracy-based nations, along with the basic values of the law state was as the counterweight, so that teh contained power in the democracy will be more directed and will not deviate from the goal of basic values in the national and state life.

From the explanation above, we can pull out a main problem which can be formulated related to the Deliberation and the meaning of democracy perspective-based sovereignty of people in the Pancasila values, that is in the democracy implementation or in the sovereignty of the people with the deliberation principals based on the the ideal foundation of Pancasila and 1945 constitution of the Republic Indonesia.

\section{METHODOLOGY}

This research was done by using the descriptive philosophical normative study method. The secondary law materials in this writing was taken from the literature, papers, journals, as well as the other researches related to this writing.

\section{DISCUSSION}

\section{Democracy in the Society Consultation Concept}

As we knew that the meaning of Democracy which initiated from the words demos and kratos which means the government from the people, for the people and by the people. The democracy conception always put the people in the most strategic position.

In the history of democracy development, in the ancient democracy era in Athena, was used the pure democracy work model form or the direct democracy. The direct property of the ancient Greek was abled to be hold effectively due to the restricted area condition and the society character which was still modest and simple.

The modern countries were no longer possessing modest or simple characteristic and their territory is already big enough and the number of the people around the society was already enough with the presence complexity which made the democracy implementation to be indirect or representative democracy, where the people elected their representatives to state their manner as the reality they should handle (Miriam Budiardjo, 1986). After the end of Greek era, the islamic thinkers had taken the nature law which stated that," human is a social animal." Human are abled to stay survive if became the 
society member, no one except for the Almighty Allah SWT, that was abled to live alone by their own selves, Human was created to live together. (Politics I,Ernest Barkers translation, 2017).

The establishment of Madinah Charter was one of the tactic of the Prophet after moved in Madinah, that was meant to build the unity of life from several groups of Madinah citizen. In the charter there were formulations about the religious freedom, inter-group relations, the obligation to maintain the unity of life, and so on. According to the Madinah Charter content, the complex Madinah citizen politically supervised by our Prophet Muhammad SAW. (Dahlan Thaib dkk. 2015). So that, Our Prophet in the organization of the Madinah Charter together with the society groups which have fused themselves and struggle together, whereas previously the Prophet had been stated as the politic and religion leader. So that, the Madinah Charter had organized democraticly because it came from a democracy process.

The implementation of the democracy life values unabled to avoid the need of support from the society in the organization of the state administration. All the decisions from the government unseparatedly from the society idea/ opinions in the form of voice, supervision, and participated in the formulation and the implementation process all the policies taken by the government. Practically, the democracy principals or the sovereignty of the society were abled to guarantee the society role in the decision making process, so that each regulation which had been established or implemented were properly representing the feeling of society justice. However, democracy was not the only form of arrangement in national and state life. There were the other formulation which also abled to use for decision making. Yet, this democracy system was expected to be the most comfortable and parted us away from the injustice. It was due to, with the democracy system, the right of the citizen is a main power in the nation implementation.

In several state systems which used their citizen as the source of their legitimation, the representation system became the rational system. This rationality could be explained with one comprehension that, in the social life there will be a room for plurality. It could be controlled without put forward the anarchi roles and domination of one groups over another.(Dahlan Thaib, 1999).

Hans Kelsen stated that, basically democracy is a government from the people and to the people. With the acceptance of the Kelsen descriptions about the basic of democracy, so we could now answer that;

1. The one who performs the democratic country power was the selected society representation to which the society believes that, all their wills and interests would be considered to perform the country power.

2. One way to perform the democratic country power was to always remember the society wills and interests, so that in each action to perform the country power was not conflicting with the will as well as the interest of the society, that should always tried the best to fulfil the society will and interest.

3. The number of the democratic country power which abled to be performed has not determined by the numbers, yet as much as possible to obtain the expected results by the society, as long as it was not deviate from the basic of the main democracy.(Christine S.T. Kansil, 2004)

In this moment, almost all of the country thought that their country is based on the democracy or as the sovereign state of the people, even the communist belief countries admitted that their governmental system was based on the democracy or based on the sovereignty of the people. So that, the meaning of democracy or the sovereignty of the people became larger, depend on each country implemented it. As stated by Dahlan Thaib, that the principle of democracy contained two meanings, they are: 1) Democracy connected to the governmental system; in this case the problem was laid on the citizen role in the governmental administration, 2) the principle of democracy which was influenced by the history, socio-cultural from the nation itself so that brought up the constitutional democracy terminology, society democracy dan pancasila democracy (Dahlan Thaib, 1999). In the modern countries which were not simple anymore related to the democracy implementation. It was due to the characteristics and its territory which was large already as well as the number of their society that already pretty much with the possible complexity making the democracy implementation turned out to be undirect democracy or the representative democracy, to which the citizens were choosing their representatives to state as the reality which should be performed. Looking at those reasons above the need of the legal device to keep the national and state life. As stated by Satjipto Rahardjo, that the overview was not looking at the law only as a logic and consistent system, which were separated from its social environent, yet it should looked a law as an institution which always related to its public order, it always being accused to give more attention between the law and the social fact which lived and developed. Law should not be the esoteric realm or the region only, which could only and abled to be entered by the policies maker, the law authority, and the lawyer, eventhough their thought were specialistic, which frequently only struggle with the "rules and logic" until this day that the way of thinking and the law performance as mentioned before were still 
dominant, that commonly known as the term of analilytical jurisprudence or rech dogmatiek in the law sociology. (Satjipto Rahardjo, 2004)

Muhammad Yamin utilized the word law country same with rechtsstaat or government of law, clearly explained that:"Republic of Indonesia is a law-based country (rechtsstaat, government of law)..., was not a police-based or military-based country... was not a state power also (machtsstaat)...".(Muhammad Yamin, 1982).Notohamidjojo, use the terminology of the law- based country or rechtsstaat".(Notohamidjojo,1970). Sudargo Gautama stated that:" in a law-based country, there were a country power restriction for personal/ private..., this term by the law experts from the England was commonly known as the rule of law (Sudargo Gautama, 1983). Besides Ismail Suny also used the term of the rule of law in the enforcement of law-based country," ..... the ensurement of the law was not abled in the whole meaning in our Nation, the rule of law absent in Indonesia, our country is not even a law-based country...." (Ismail Suny,1982). Indonesia as a country which embraced the democracy system or the sovereignty of the peopple, so that in the governmental implementation could not separated from the society participation to determine the flow of the government as well as the direction of the country development. In the implementation of the sovereignty of the people it was not fully carried out by the society eventhough the 1945 constitutional of Republic Indonesia had already being amendmented so that the administration or implementation of the government was successfully carried out democraticly. It was due to the development as well as the growth of the nation and the society which occured rapidly especially in the field of sovereignty of people..

The principle of "popular sovereignty" states that there is no human being, or an elite, or a group of ideologies, or a group of priests / pastors / ulama have the right to determine and impose (demand by using threats) how others should or may live. Democracy is based on the awareness that those who are led have the right to determine who leads them and where they want to be led. Democracy is "people's sovereignty plus the principle of representation". (Jimly Asshiddiqie, 1994)

As a theory, none of the teachings about popular sovereignty can be called the most modern. It's just that it must be recognized, almost all modern countries today, formally claim to adhere to the principle of popular sovereignty. (Jimly Asshiddiqie,1994)

Asas Kedaulatan Rakyat atau paham demokrasi mengandung dua arti:

a. Democracy which is related to the government system or how people are included in the administration of government.

b. Democracy as a principle influenced by, the cultural, historical condition of a nation that in the end occurred terms, constitutional democracy, people's democracy and Pancasila democracy emerge.

c. Along with the changing times, the implementation of popular sovereignty or modern democracy is a democracy with a system of representation, meaning that people choose someone from themselves to represent it. In connection with the system of representation in the context of popular sovereignty, as stated by Robert Dahl, see that large-scale government of the people (nation-state) can only be formed with a system of representation as a form of democratic government, a government that is sovereign of the people.

\section{The Influence of Islamic and Western Democracy on the Implementation of Deliberation and the Meaning of Democracy in Pancasila.}

The concept of democracy in fact emerged from the West (Europe), but the democratic values actually existed in Islam. As we know with the Medina Charter which was raised by the Prophet Muhammad and Muslims in Medina is the first concept in the Islamic world regarding democracy. Ziauddin Sardar stated that so that humans can be more wise and wise to nature, science must stand in the form of values: first, the principle of monotheism, which implies that the entire universe, heaven and earth, all of its contents are at the will of God. Second, the Principle of Khilafah and Mandate, namely human presence on earth in order to carry out its function as khalifah (2:30), which is mandated by God to prosper and preserve the natural environment. Everything is done in the context of worship of God (51:56). Third, the Sharia Principle, namely in order to be a good human being, then what is done in life in the world, including in carrying out natural management must be based on shariah provisions. Implications in the field of law (shari'ah) in the form of things that are allowed (halal) and may not (kharam) are done by humans. Humans as noble creatures, leaders (caliphs) are not allowed to do damage and exploitative (facade) on earth, and to waste. Calling for good deeds (Ikhsan), in the form of sustainability, and reconciliation for peace. (Absori, 2014)

In the perspective of transcendental jurisprudence, jurisprudence is not only based on truth at the level of haqq alyakin, which is gathered in the Qur'an and Hadith, but which is based on truth obtained by the ability of human potential through contemplation, reasoning and discourse that develops in 
society. Humans explore process and formulate knowledge with the aim not only for knowledge but also for policy, the benefit of the wider community, with the pleasure and love of God. (Absori, 2015)

In the teachings of Islam it has also set the life of society, nation and state as the implementation of shura or deliberation. In terms of language (etymology) lafaz al-Shura and al-Musyawarah and alMasyurah is a form of masdar fi'il (verb) of the word syâwara-yusyâwiru which is root of katasyin, waw, and ra 'in the fa'ala pattern. The root structure of the word means the principal "show and offer something" and "take something" from this last word comes from the phrase syâwartu fulânan fi amrî: "I take Fulan's opinion regarding my business". (Badan Litbang dan Diklat Departemen Agama RI: 2009). Therefore, in a democratic system, society is the source of law. The law in question is that which supports fundamental rights that guarantee the existence and interests of individuals as part of a sovereign community. This issue of sovereignty, according to Abou El Fadl, is central in the discourse of democracy. Whereas classical Juris as puritans believe that the principle of sovereignty in a democratic system is not legitimate, because God is the sole owner of sovereignty and the source of law. Democracy in this case is considered to have doubted God. (Abou El Fadl, September 2009).

It can be ascertained, the founder of the country at that time that the Indonesian State had a specific goal, namely, so that the Indonesian state would later not fall into a certain group or political power, but instead belonged to all Indonesian people who in their constitutional reality recognized their sovereignty. Especially considering that, Indonesia, which has a very large area and a pluralistic composition of society, then democracy in the practice of state administration is carried out with a model of indirect democracy or representative democracy based on Pancasila as the ideal foundation and the 1945 Constitution as a constitutional basis.

The ideal foundation of Pancasila is contained in the fourth paragraph of the Preamble of the 1945 Constitution as a constitutional foundation, which is the basic philosophy of the purpose of establishing the Republic of Indonesia. The sovereignty of the people is based on the perception that, in fact, it is the people who hold the highest authority in the state, not the authorities or state administrators. Authorities tend to maintain and expand their power, so there needs to be restrictions on these powers. The foregoing that in the implementation of democracy or people's sovereignty cannot be separated from deviations. The people's sovereignty stems from the perception that, in fact, it is the people who hold the highest authority in the state, not the authorities or state administrators. Authorities tend to maintain and expand their power, so there needs to be restrictions on these powers.

Provisions in the Preamble to the 1945 Constitution the fourth paragraph implemented in Article 1 paragraph (2) of the 1945 Constitution of the Unitary State of the Republic of Indonesia, which states that before the amendment states that, "Sovereignty is in the hands of the people and fully carried out by the People's Consultative Assembly " and compare it to Article 1 paragraph (2) of the 1945 Constitution of the Republic of Indonesia after the change, that, "Sovereignty is in the hands of the people and implemented according to the Basic Law ".By looking at the 1945 Constitution of the Republic of Indonesia, it can be concluded that the Indonesian State follows the model of indirect democracy or representative democracy.

The term deliberations, has been listed in the 1945 Constitution, RIS 1949 Constitution, and 1950 Constitution. In the process of preparing the 1945 Constitution, the term deliberation was first conveyed by Muh. Yamin in his speech May 29, 1945 in front of the BPUPKI Session referring to Al-Qr'an Surat AsyShura verse 38 which means ".... all their affairs are deliberated ...". There are three basic things from the urgency of deliberation for the progress of the state in the protection of God, namely; 1). Broadening horizons, 2). Togetherness in responsibilities, 3). Minimize erroneous establishment or behavior. Muh. Yamin also gave a thought that among the Islamic countries in the world, the Indonesian people gave a special color in the implementation of the life of the nation and state life.

(Moh. Yamin, 1971).

Thus it can be concluded that the founding fathers do not want a liberal democracy. Therefore, the concept of deliberative democracy was chosen, as outlined in the formulation of the fourth precepts of Pancasila. This thought is special because there is a contribution of Islamic thought. While the results of the concept of deliberation in the socio-political and cultural context of society are, first, deliberation as solidarity, strength and independence of individuals and their rights as human beings, secondly, deliberation can be said as an instrument of da'wah if deliberation can become a place to glorify and guide someone towards a better direction, the third is, deliberation as a social principle and the fourth is deliberation as khilafah following its fitri rights.

The opinion of the founding fathers of the Republic of Indonesia determined that the state which was to be established was based on the people's consultation principle as the basis of a democratic state. Democratic government, is every problem will be deliberated and resolved in the people. 
The 1945 Constitution, contains the principles of deliberation that are set out in the Articles of the Body of 1945 Constitution which have an impact on the administration of government both at the central and regional levels. However, in the implementation of consultation by the people directly, of course it cannot be held in Indonesia. This is due to the territorial conditions, number and diversity of Indonesian people, then the Republic of Indonesia, using a modern democratic system or indirect democracy or in the administration of its constitution is called a representative system democracy. However, the implementation of democracy with a representative system is not as simple as direct democracy. In the exercise of power in the Unitary State of the Republic of Indonesia, before Indonesia was made as a state, it has used the principle of deliberation, which is the sovereignty of the people as the basis for carrying out community life. As stated by Padmo Wahjono that, in the state administration, deliberation is a dialogue or deliberation by paying attention, a). community dynamics, b). everything that happens, c). all streams. (Padmo Wahjono, 2014).

From this formulation, the nature of deliberation contains the principles, among others namely; 1 ). Togetherness in negotiating and solving problems, 2). Similarities in conveying interests, 3). Tolerance in differences in class and opinion, 3). Open to all the flow and dynamics that occur in society.. (Andi Pangerang, 1999).

The problem to be faced with indirect democracy or representative system democracy is that the state must form an institution to organize or act as the sovereignty of the people. Institutions that are formed must truly represent the people as holders of people's sovereignty. Therefore the establishment of representative institutions must reflect democratic values in order to carry out the mandate of the people well. Besides that, rules are also needed to regulate the implementation of democracy with an indirect model or a democratic system of representation. An indicator that qualifies democratic practice in Indonesia is the function of people's representative institutions. The unitary state of the Republic of Indonesia is a country that embraces democracy, in which the people participate in determining the course of the government and the direction of development. As a country whose territory and plural society makes Indonesia use indirect democracy or democracy with a representative system. Therefore, the implementation of people's sovereignty before the amendment of the 1945 Constitution is to show that people's sovereignty has been fully implemented by a representative body, namely the People's Consultative Assembly (MPR) as stated in Article 1 paragraph (2) of the 1945 Constitution. Thus the People's Consultative Assembly occupy a position as the State's Highest Institution. As also emphasized in the Elucidation of the 1945 Constitution in the seven main key systems of government no. III, that the People's Consultative Assembly is the incarnation of all Indonesian people.

Over time, the administration of government in Indonesia does not reflect democratic values, therefore the Indonesian people make a change. This is so that the 1945 Constitution as a source of state administration needs to be changed in order to create a more democratic government.

In the third amendment to the 1945 Constitution, Article 1 paragraph (2) of the 1945 Constitution concerning the position of the People's Consultative Assembly (MPR) as a representative institution, has been amended. Even though the position and authority of the People's Consultative Assembly experienced a shift, the duties and authority of the People's Consultative Assembly as the bearer of People's Sovereignty were not lost. In fact, the People's Consultative Assembly was formed more democratic than before the 1945 Constitution underwent a change. All MPR members, consisting of members of the House of Representatives (DPR) and members of the Regional Representative Council (DPD), are formed through a general election process that is directly elected by the people.

In the fourth paragraph of the Preamble of the 1945 Constitution, the founders of the State have taken political decisions in the process of establishing a state, namely:

"To form an Indonesian government that protects all Indonesian people and all Indonesian blood and to promote public welfare, educate the nation's life and participate in carrying out world order based on freedom, eternal peace and social justice, then the Indonesian national independence was arranged in a Constitution of the Republic of Indonesia, which was formed in an arrangement of the Indonesian state, which sovereignty of the people based on the Godhead of the Almighty, just and civilized humanity, the unity of Indonesia and the populace led by wisdom in Consultation / Representation, and by realizing a social justice for all Indonesian people".

By looking at the provisions above, it shows that the Basic Law has the character of a modern statutory regulation. This is because that the modern state in general is based on democracy or a sovereign state of the people. Besides that, it is also known that the influence of Pancasila on the development of democracy in the life of the nation as a state, especially in the context of facing this globalization. All challenges and hopes, then with Pancasila as the ideology and basis of the country is expected to be resolved and can unite the diverse nation of Indonesia and its interests. 
Provisions in the Preamble to the 1945 Constitution on the fourth paragraph are then implemented in Article 1 paragraph (2) of the 1945 Constitution of the Unitary State of the Republic of Indonesia, wherein before the amendment states that, "Sovereignty is in the hands of the people and fully exercised by the People's Consultative Assembly "And compare with Article 1 paragraph (2) of the 1945 Constitution of the Republic of Indonesia after the amendment, that," Sovereignty is in the hands of the people and implemented according to the Basic Law ". By looking at the 1945 Constitution of the Republic of Indonesia, it can be concluded that the Indonesian State follows the model of indirect democracy or representative democracy based on consultation values.

Likewise, in Jakarta Charter it is a document stipulated by BPUPKI June 22, 1945, there is a formula which reads; Godhead by carrying out Islamic sharia for his adherents. The formulation changed when the 1945 Constitution was stipulated by PPKI on August 18, 1945 to be; Belief in the one and only God. With the change in the formulation, it shows that the democracy contained in the Preamble to the 1945 Constitution, eliminates one of the thoughts that the Indonesian state pays attention to the privilege of the largest population, which is Muslim. Thus, the sociological representation of Islam in the life of democracy in Indonesia is also missing in the form of the enactment of Islamic sharia. Democracy is really based on the idea of nationality which is solely based on the values of independence or freedom and sovereignty of the people.. (Aidul Fitriciada Azhari, 2017).

Together with ideas from Islamic thought and tribal traditions in Indonesia, the idea of modern democracy also influenced the formulation of the 1945 Constitution. Therefore, the 1945 Constitution is insepereble from all kinds of complexity of problems inherent in the ideas of modern democracy. For this reason, the discussion on the idea of democracy in the 1945 Constitution will begin first with a review of the basic ideas of modern democracy developed among European and American thinkers. The study on the idea of modern democracy is needed to be able to trace the influence of the idea of democracy that developed in the 1945 Constitution and its contact with the notion of democracy that originates from Islamic teachings and traditions of the Indonesian people whose influence was also very strong in the formation of democratic ideas in the 1945 Constitution. (Aidul Fitriciada Azhari, 2017).

However, we know together that the ideology or ideals of democracy championed by the country's founders and leaders of the Indonesian movement, that the establishment of the Republic of Indonesia is inseparable from the achievement of the compromises and formulations as contained in the Preamble to the 1945 Constitution, which by Hatta contains three basic statements; 1). Basic statement of politics and ideals of the Indonesian people, 2). Statement about the success of the political demands of the Indonesian people, with the gift of God, 3). Statements about Pancasila as the philosophy or ideology of the state, namely the Almighty God, Humanity, Indonesian Unity, Democracy, and Social Justice. If observed, then Pancasila has 2 basic things; first, morals, namely the Almighty God, second, politics, namely Humanity, Indonesian Unity, Democracy, Social Justice. (Moh. Hatta, 1960)

\section{Implication}

Based on the description above, then a conclusion can be drawn, that the unitary state of the Republic of Indonesia is a country that adheres to the understanding of democracy, where the people participate in determining the course of government and the direction of development. As a country whose territory and plural society makes Indonesia use indirect democracy or democracy with a representative system. Therefore, the implementation of people's sovereignty before the amendment of the 1945 Constitution is to show that people's sovereignty has been fully implemented by a representative institution, namely the People's Consultative Assembly (MPR) as stated in Article 1 paragraph (2) of the 1945 Constitution.

Besides that, the 1945 Constitution has values in the matter of consultation, namely by continuing to uphold human dignity. Besides that, prioritizing deliberation in solving problems, by recognizing diversity and heterogeneity in society, but prioritizing togetherness rather than the interests of groups or individualism.

Therefore, the People's Consultative Assembly before the 1945 Constitution was amended, occupied the position of the Supreme State Institution. As also emphasized in the Elucidation of the 1945 Constitution in the seven main key systems of government no. III, that the People's Consultative Assembly is the incarnation of all Indonesian people. Over time, the administration of government in Indonesia does not reflect democratic values, thus the Indonesian people make a change. This is so that the 1945 Constitution as a source of state administration needs to be changed in order to create a more democratic government in the values of consultation.

In the third amendment to the 1945 Constitution, Article 1 paragraph (2) of the 1945 Constitution concerning the position of the People's Consultative Assembly (MPR) as a representative institution, has been amended. Even though the position and authority of the People's Consultative Assembly experienced a shift, the duties and authority of the People's Consultative Assembly as the 
bearer of People's Sovereignty were not lost. In fact, the People's Consultative Assembly is formed more democratic than before the 1945 Constitution underwent a change. All MPR members, consisting of members of the House of Representatives (DPR) and members of the Regional Representative Council (DPD), are formed through a general election process that is directly elected by the people.

Thus, Democracy in the values of deliberation, that on one side of democracy is as a modern social political system that prioritizes the interests or power of the authorities located as representatives of the people, while the values of deliberation are as part in solving all the problems that exist in life humans themselves, both in their individual lives or in human life as part of the life of the nation, community and state, are resolved while respecting the pluralism that exists in Indonesian society or people.

\section{REFERENCES}

Absori, Idea of Pancasila Law, Variety of Legal Paradigms with Indonesian Personality, Kartasura, Solo, Pustaka Iltizam, 2016.

-------, Transcendental Law Epistemology and Its Implementation in the Development of the Legal Science Doctoral Program, Paper at the National Seminar with the theme, "Development of Legal Science Epistemology", 11 April 2015, Muhammadiyah University of Surakarta.

Aspinall, Edward, Ward Berenschot, 2019, Democracy For Sale, Cornell University Press Ithaca and London

Andi Pangerang, People's Consultative Principles based on Article 18 of the 1945 Constitution and Its Implementation in Regional Government Systems, Dissertation, Padjadjaran University Postgraduate Program, Bandung, 1999

-------, et al, Prophetic Law Paradigm: Criticism of Non-Systemic Legal Paradigm, Genta Publishing, First Edition, Yogyakarta, 2015

Anton F. Susanto, Non-Systemic Law, Foundations of Philosophy of Development of Indonesian Law, Genta Publishing, Printing I, Yogyakarta, 2010.

Aidul Fitriciada Azhari, Tafsir of the Constitution; The Struggle to Realize Democracy in Indonesia, Genta Publishing, Issue II, Yogyakarta, 2017.

C.S.T. Kansil and Christine S.T. Kansil, State Science, PT Pradnya Paramita, Second edition, Jakarta, 2004.

Dahlan Thaib, Kedaulatan Rakyat State Law and Constitution, Yogyakarta, Liberty, 1999. -- et al, Constitutional Theory and Law, Jakarta, PT Raja Grafindo Persada, 12th edition, 2015.

Ismail Sunny, Seeking Justice, Jakarta, Ghalia Indonesia, 1982

Janedjri M Gaffar, Constitutional Democracy in Indonesian State Administration Practices After Amendment to the 1945 Constitution, Jakarta, Constitution Press, 2013

Jimly Asshiddiqie, Ideas of People's Sovereignty in the Constitution and Its Implementation in Indonesia, P.T Ictiar Baru Van Hoeve, Jakarta. 1994

--------, Towards a democratic rule of law, Jakarta, PT Bhuana Ilmu Populer, Gramedia Group, 2009

Miriam Budiardjo (ed), State Issues, Jakarta, Gramedia, Cet. IV, 1982 , Various Thoughts About Power and Authority, Sinar Harapan, Jakarta, 1986.

Moh. Hatta, Our Democracy, PT. Pustaka Antara, Jakarta, 1960

Muhammad Yamin, The Preparatory Text for the 1945 Constitution, Jakarta, Siguntang, Cet. Second, 1971. , Manuscript of the Proclamation and Constitution of the Republic of Indonesia, Jakarta, Ghalia Indonesia, 1982

Notohamidjojo, The Meaning of the Rule of Law, Jakarta, Christian Publishing Agency, 1970

Soerjono Soekanto, Use of Sociology of Law for Laws, Bandung: Citra Aditya Bakti, 1989.

Sri Soemantri M. and Bintan Saragih, Pancasila Democracy According to the 1945 Constitution in Indonesian State Administration in Indonesian Political Life, Jakarta, Sinar Harapan, 1993.

Sudargo Gautama, Definition of the rule of law, Bandung, Alumni, 1983

Satjipto Rahardjo, "Progressive Law for the Presidential Election", in a Kompas Daily Article, September 20, 2004.

Siti Hasanah, Strengthening the Tradition of Deliberative Consensus in the State Power System: Studies on the present and future MPR institutions, Proceedings of the National Seminar on "Development of the Epistemology of Law Science".

K.C. Wheare,, Modern Constitutions, Euraka Library, 2003.

Journal Abid Rohmanu, Pluralism, Democracy and Social Justice in the Concept of Humanistic Fiqh Abou El Fadl, Journal of ISLAMICA, Vol. 4 No. 1, September 2009. 
Dahlan Thaib, People's Representation in the MPR: In terms of Political and Legislative Infrastructure, Journal of Magister Hukum, Vol. 1. No. 1, September 1999.

Muhammad Hanafi, The Position of Deliberation and Democracy in Indonesia, Journal of Cita Hukum. Vol. I No. December 2, 2013.

Tsalis Rifa'I, Communication in Deliberation (Overview of Ashura Concepts in Islam), Journal, Channel, Vol. 3, No. 1, April 2015

Politics I, Ernest Barkers translation, 2017

http://www.academia.edu/ PAPER EDUCATION PANCASILA

Daרvid Altman (2000) in The Politics of Coalition Formation and Survi-val in Multiparty Presidential Demo $\urcorner$ cracies: The Case of Uruguay 1989-1999

Fukuyama, Francis, 2015, Why Is Democracy Performing So Poorly ?, Journal of Democracy, Volume 26, Number 1, January 2015, pp. 11-20 (Article)

James B. Hoesterey, 2017, Is Indonesia a Model for the Arab Spring? Islam, Democracy, and Diplomacy *, Emory University, https: /www.cambridge.org/core.

Mirjam Künkler \& Hanna Lerner, 2016, To A private matter? Religious education and democracy in Indonesia and Israel, ISSN: 0141-6200 (Print) 1740-7931 (Online) Journal homepage: http://www.tandfonline.com/loi/cbre20

Juliet Pietsch and Marshall Clark, 2015, Critical Citizens: Attitudes towards Democracy in Indonesia and Malaysia, School of Politics and International Relations, Australian National Universit 